\title{
Energizing middle managers' practice in organizational learning
}

Article

Accepted Version

McKenzie, J. and Varney, S. (2018) Energizing middle managers' practice in organizational learning. The Learning Organization, 25 (6). pp. 383-398. ISSN 0969-6474 doi: https://doi.org/10.1108/TLO-06-2018-0106 Available at https://centaur.reading.ac.uk/80671/

It is advisable to refer to the publisher's version if you intend to cite from the work. See Guidance on citing.

To link to this article DOI: http://dx.doi.org/10.1108/TLO-06-2018-0106

Publisher: Emerald

All outputs in CentAUR are protected by Intellectual Property Rights law, including copyright law. Copyright and IPR is retained by the creators or other copyright holders. Terms and conditions for use of this material are defined in the End User Agreement.

\section{www.reading.ac.uk/centaur}

\section{CentAUR}

Central Archive at the University of Reading

Reading's research outputs online 


\title{
Energizing middle managers practice in the organizational learning process
}

\author{
Professor Jane McKenzie \\ Dr Sharon Varney
}

Purpose: Following Chia's (2017) conceptualisation of organisational learning as wayfinding, this paper considers middle managers (MMs) influence on the process, by exploring how they cope with the demands and tensions in their role and whether their practice affects available team energy.

Design/methodology/approach: 43 managers from 3 large organisations involved in major change assessed the level of their group/team energy using a tested and validated instrument the OEQ12@. This generated 6 distinct categories of team energy from highly productive to corrosive. 34 of the 43 managers spread across these categories completed 'a twenty statements test' and agreed to a follow up interview to explore their cognitive, affective and behavioural responses to coping with the resource constraints and tensions in their role.

Findings: The research provides preliminary insights into what distinguishes a middle manager persona co-ordinating teams with highly productive energy from those managing groups with less available energy to engage with knowledge and learning. It considers why these distinctions may affect collective sensitivities in the learning process.

Research limitations/implications (optional): Informants were not equally distributed across the team energy categories, so some middle manager personas are more indicative than others.

Practical implications (optional): Points to areas where middle manager development could potentially improve organisational learning.

Originality/value: Our study offers early empirical evidence that middle managers' orientation to their role is intricately entangled with the process of energising their teams in organizational learning. They are in a pivotal position for creating the right emotional ambience for people to learn in change.

Keywords: middle managers, organizational energy, organizational learning

Article classification: Research paper 
Organisational learning has been conceptualised as a complex, social process of 'wayfinding' that emerges from practice in coping with day to day challenges and navigating change (Chia, 2017). Over time, people interact with context, collective experience changes, structures, routines and norms are adapted, new knowledge emerges and the organizational learns (Argote and Miron-Spektor, 2011, Orlikowski, 2002). Knowledge, experience and structural capital evolve at individual, group and intergroup levels (Crossan et al., 1999). The organisation is constantly becoming something new through collective praxis, which can be defined as "the pursuit of knowledge infused practice undertaken purposefully for change" (Maclntosh et al., 2017). The power of persuasion, negotiation and communication affect the interpretation of goals and actions; learning possibilities are bounded by existing systems and structures, whilst agenda setting and local decision making, restrict the range of possible behaviours (Lawrence et al., 2005). Arguably, middle managers (MMs) play a pivotal role in this scenario (Huy, 2011, Sharma and Good, 2013). They act as both sensemakers and sensegivers (Rouleau, 2005), make operational decisions in relation to the systems and structures that affect organizational development and play a balancing role in the socio-emotional climate (Huy, 2002) in which learning occurs.

\section{Middle managers play a pivotal role in shaping learning conditions}

The praxis of middle managers is pivotal in translating (Carlile, 2004) a top management team's (TMT) strategic intent for change into front line action (Raes et al., 2011 , Jermy, 2011). MMs make sense of the various conflicting demands and pressures for their team, determine priorities, provide an interface with other teams and curate the focus of learning (Raes et al., 2011, Huy, 2001, Jermy, 2011). At the same time, they maintain continuity by co-ordinating day to day team practices (Vaara and Whittington, 2012 , Graetz and Smith, 2010). They are closer to frontline operations than the TMT, but still sufficiently distanced from the daily work to see the big picture (Ahearne et al., 2014 , Huy, 2001). They both 'give and receive direction' and use 'upward and downward influence' (Ahearne et al., 2014 p. 68) to champion alternatives and facilitate adaptability. In such a pivotal position, they have a strong influence on the social habitus (Bourdieu, 1989) in which continuity and change co-evolve (Reay, 2004). Their sensemaking and sensegiving shapes the environment for collective learning, so their coping practices potentially enrich or impair the collective sensitivities and dispositions that Chia (2017) contribute to organisational resilience and inventiveness.

\section{A middle manager operates in stretching conditions with squeezed resources}

Large organizations have been progressively flattening hierarchies to achieve efficiencies, even as they relentlessly initiate changes in response to external turbulence. Hence, the MM role has become simultaneously more squeezed in terms of resources like time, money and human capital and more stretching in terms of breadth of responsibilities. In practice, re-organization places strains on networks and social capital that normally facilitate knowledge flow (Nahapiet and Ghoshal, 1998 , Kwon and Adler, 2014). MMs have to cope with paradoxical demands (Lewis et al., 2014) like maintaining stability whilst delivering change (Farjoun, 2010 , Nasim and Sushil, 2011), operating through existing routines and processes whilst simultaneously developing new ones and exploiting existing knowledge whilst learning and innovating. For MMs to maintain their reputation with senior managers at the same time as credible influence over those they manage (Ahearne et al., 2014), they are stretched to recognise and accommodate multiple agendas.

Consequently, the role of a middle manager is imbued with tension even as it becomes less clearly defined and job security less predictable (Currie and Procter, 2005). It is plausible to assume that 
lack of clarity will make the sensemaking and sensegiving aspects of their role harder (Lüscher and Lewis, 2008, Rouleau, 2005). When combined with a tenuous sense of control over results and uncertain job prospects for themselves and their teams, the tension is likely to undermine their sense of psychological safety and emotional equanimity, which in turn may affect their capacity to energize their teams.

\section{Middle managers' capacity to cope with tensions in their role may affect team energy}

Emotions, moods and dispositions are known to affect arousal and energy for action (Seo et al., 2010 , Shepherd et al., 2011, Voronov and Vince, 2012). Scholars have found that the extent of MMs' emotional commitment to change affects whether the organization as a whole can learn and adapt (Huy, 2002) and whether there is sufficient momentum to implement the strategy (Huy, 2001, Huy, 2011). In conversations with their teams, MMs both generate and are affected by the emotional climate (Quinn and Dutton, 2005). The positive or negative cognitive and emotional forces MMs exert on the habitus are likely to affect mobilisation of the social, cultural, symbolic and economic capital involved in learning (Voronov and Vince, 2012). Where that climate is negative, MMs should play a role in alleviating the tensions and strains in their teams (Vijay and Vazirani, 2011, Naiman, 2009 , Siddiqi et al., 2012), But only if they feel they have sufficient resources to do so in face of other task demands (Quinn et al., 2012).

Arguably, MMs orientation to their role will influence whether their teams feel energized to engage with organizational goals. (Cole et al., 2012). The collective energy in the habitus may positively or negatively shape dispositions towards learning and change. Scholars (Cole et al., 2004 , Cole et al., 2005 , Cole et al., 2012) have characterised team energy in four ways, two positive states and two negative ones. Positive energy can take two forms, 1) productive, which is characterised by an intense positive emotional state, high alertness, a high level of activity and effort to deliver on shared goals, 2) comfortable, characterised by satisfaction with the status quo, and lower level of effort and tension, and less alertness. Negative energy can either be 3) corrosive, characterised by high level of activity and emotional tension, internal fights and micro politics or 4) resigned inertia, characterised by indifference, inner withdrawal, frustration, detachments and reduced activity. This provides a framework from which to explore the connection between MMs orientation to role and team energy and gain insight into MMs influence on ambient conditions for learning and change. The aim of this research was to understand what differentiates MMs who positively energize their teams from those who do not.

\section{Research design: How do middle managers' orientations to role affect team energy?}

The research was conducted in three large organizations- one private and two public sector. Each was engaged in a rolling out a major change initiative and senior sponsors were concerned that the resultant stretch and squeeze on MMs would compromise the flow of knowledge and learning. The research followed an interactive process (Van Winkelen et al., 2008, Van Winkelen and Truch, 2002) in which academics from Henley Business School worked in partnership with representatives from each organisation in a form of engaged scholarship (Van de Ven, 2007, Van De Ven and Johnson, 2006). The problem emerged from discussions with industry practitioners involved in organisational learning and change management. Academic partners provided the theoretical foundations and a research design framework. Organizational representatives contextualised the problem, facilitated access to MMs known to be directly involved in energising change, and provided insight and reflection on emerging findings to aid interpretation of the data in the light of environmental 
conditions. Thus, the findings emerged from an iterative and collaborative process of analysis and informed reflection.

Data was collected in two-stages.

An organisational sponsor promoted the research internally to relevant MMs. They sent a preagreed message containing a link to a previously tested and validated 12 -item organizational energy survey instrument, the OEQ12@ (Bruch and Vogel, 2011, Cole et al., 2012). 43 middle managers across the three organisations self-assessed the energy profile for their team. Analysis of responses produces a plot of team energy indicating the relative proportion of productive, comfortable, resigned and corrosive energy that each respondent assessed as present in his or her team at that point (see Table 1).

34 of the 43 agreed to provide further qualitative data about themselves and the challenges they face as MMs. Of the 9 people who refused a follow up, 5 assessed their team as having highly productive or comfortably productive energy and 4 had teams with more negative energy profiles.

The remaining 34 informants provided two sources of qualitative data, 1) A 20 statements test (TST) originally devised by Kuhn and McPartland (1954), which provides rich insights into an individual's mindset, preferences and attitudes to self in role. Informants were asked to write 20 statements in response to the question "who am I, as a middle manager?" and 2) a semi structured interview exploring how they experienced the demands of their role. Each interview lasted around 45 minutes. Questions covered the most serious resource constraints, the tensions arising from the contradictory demands of their role and the managers affective, cognitive and behavioural responses.

All interviews were conducted in confidence by researchers outside the three participating organisations. When requested, interviews were conducted offsite or by phone to allow respondents to express negative feelings and views about their middle management status.

Statements on the TST were coded in three ways: 10 in line with McPartland's approach, as physical, social, reflective and oceanic; 2) using Rees and Nicholson's (2004) orthogonal coding of skills and abilities, interests and needs, character and behavioural style, and values and beliefs; 3 ) there was evidence in the responses of two different attitudes to self in role. One represented by a tendency to start statements with 'I am...' representing personal identification of themselves with the characteristic described. These were inductively coded as owned. Unusually, some statements were expressed in a more detached manner e.g. 'someone who...', 'responsible for...' 'required to'. These were coded as objective and detached. Sometimes both owned and detached styles were part of an individual's statements, sometimes one dominated.

The OEQ12@ plots of those interviewed fell into six typical team energy profiles. Table 1 shows a characteristic profile plot, names the profile and shows the proportion of the $34 \mathrm{MMs}$ whose teams exhibited this profile. The TST analysis and the qualitative interview data were used to compile a persona for each of the 34 middle managers. The personas were sorted into the six categories of team energy profiles and examined for commonalities. This made it possible to distinguish the notable characteristics of a representative MM persona (Miaskiewicz and Kozar, 2011) for each energy profile. A short descriptor of typical orientation to the middle manager role was developed for each of the six energy profiles. The general persona profile and descriptor were reviewed by representatives from the three organisations involved in our study for internal consistency and in the light of their experience of prevailing contextual conditions. 
Table 1: Team energy profiles

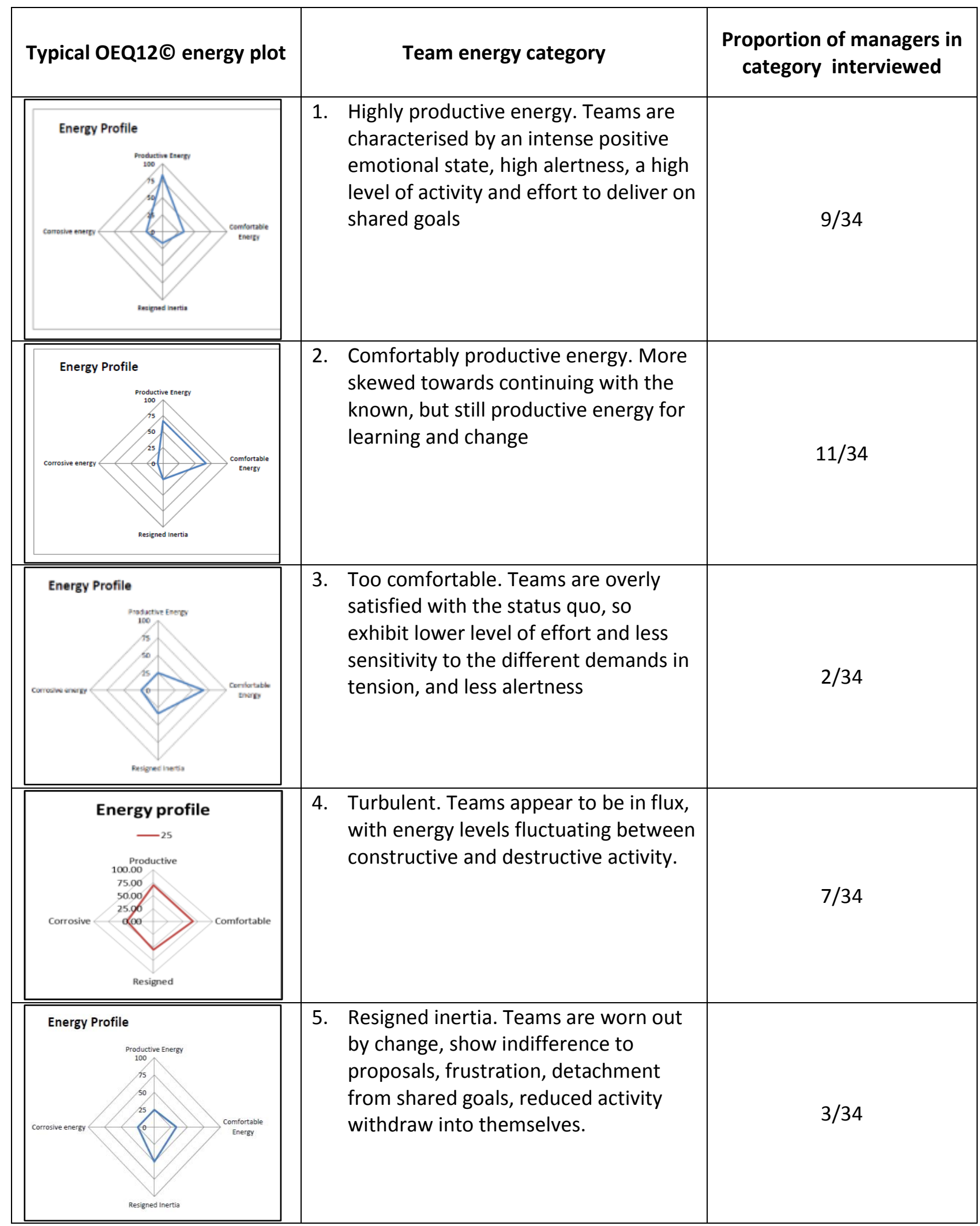




\begin{tabular}{|c|l|l|l|}
\hline Energy Profile & $\begin{array}{l}\text { 6. } \\
\text { Largely corrosive. Teams exhibit a high } \\
\text { level of activity associated with } \\
\text { emotional discontent, internal fights } \\
\text { and micro politics. }\end{array}$ & $2 / 34$ \\
\hline
\end{tabular}

Collectively the TST data alone surfaced over 50 aspects of the MM role. One manager in the comfortably productive energy group defined himself as a translator, a transmitter and receptor, a defender of freedom, a functional link, a policeman, an authority, a wizard, a builder, a competitor, a coach an accountant, a transformer, an intelligent machine, a cook and an optimist, qualifying each with the relevant activity related to his role. He concluded, 'I do a lot. I try to think and innovate to reinvent myself and my environment.' This was not unusual. When combined with the interview data a picture emerged which confirmed that MMs face multiple tensions due to squeezed resources and accumulating change initiatives. $20 \mathrm{MMs}$ still had teams where some productive energy would be available for learning. 12 managed teams where turbulent, resigned and/or corrosive energy would consume resources, leaving less space for learning. 2 evidenced extreme comfort with the status quo suggesting less stimulus to learn and change.

The six general personas developed from MMs in the six energy profile groups were quite distinctive

Type 1: A self-confident leader with a voice that is heard. Middle managers in this group have teams with high levels of productive energy. They personally own and identify with what they do: it is who they are. Middle managers with this orientation feel they can influence upwards and place less emphasis on their position in the social structure than those with a Type 2 orientation. While they are reasonably reflective, what is notable about this type is that they tend to have a higher proportion of positive reflective statements about themselves. They largely have a positive orientation towards change: they are excited about the prospect of doing something new and about doing things better. They are keen to convey the meaningfulness of change to others and they are concerned about resource deficiencies in relation to that aim. Type 1 middle managers know how to balance the big picture and detail.

Type 2: An officer with responsibilities for delivering results. Middle managers in this group have teams with high levels of comfortable energy as well as productive energy. In contrast to Type 1 , they tend to explain their role, skills, behaviours and responsibilities in a detached way, as someone who is responsible for or is expected to do something. They tend to describe themselves through social roles and their position in the social structure. This type of middle manager is typically less reflective about themselves and their role than Type 1 managers, which may mean that there is less opportunity for them to learn new things. They are excited by efficiency, doing things better and want to deliver performance. They can be dissatisfied with others' lack of curiosity, sense of urgency, or motivation to explore. The managers in this group were split almost 50:50 in terms of their sense of a capacity to influence upwards.

Type 3: A team player who engages with the familiar and known. Teams here have high levels of comfortable energy. This group of middle managers was too small to draw strong conclusions. However, while this type owned the statements about their role, they were the least reflective of all 
the six types. An examination of the detail of their profiles suggests that they are highly affiliated with their teams.

Type 4: Ambivalent about their position and feeling conflicted and vulnerable. The energy profiles for these teams was turbulent: high on all four energy categories. MMs were ambivalent about whether they personally identified with their actions (I am...) or could detach themselves from their role (responsible for...). They also expressed divided loyalties in handling team and organizational needs, talking of themselves as being caught between conflicting priorities. They showed strong team affiliation with a focus on delivery and performance but were typically unconvinced about the change. They struggled to distinguish big picture priorities from detailed requirements. This was the most reflective group. Notably, many of their personal reflections focused on constraints, negative aspects of the situation and themselves, or self-criticism. They also focused on resource deficiencies such as a lack of relevant skills, time, and capacity.

Type 5: Emotionally exhausted by uncertainty and the volume and nature of demands. The energy profiles for teams that were high on resigned inertia. This group of middle managers was too small to draw strong conclusions. The sense of ownership or being detached from their role was mixed. Reflections focused on issues relating to the gap between expectations and capacity to deliver. There was a lack of emotional commitment to the change and a sense that expectations exceeded their personal capacity to cope with them.

Type 6: Fish out of water, struggling to survive. Here the team energy profiles were high on corrosive energy. This group of middle managers was too small to draw strong conclusions. They tended to take a detached view of themselves in their role. Personal reflections about themselves were very positive, yet the rest of their interview suggested a sense of frustration and incapacity to have an impact through their chosen approaches. They focused on resource deficiencies associated with psychological safety e.g. no sense of influence, no support. Their inability to see their way out of an emotionally overwhelming combination of demands made them feel inadequate in their roles.

Table 2 provides a summary of the orientation of each persona, the proportion of the 34 informants in each category $(n)$ against the team energy profile and the analysis from the TSTs and interviews with indicative quotations in italics. 
Table 2: Middle manager orientation to the requirements of their role

\begin{tabular}{|c|c|c|c|c|}
\hline \multirow{2}{*}{$\begin{array}{l}\text { Source } \\
\text { Orientation to the } \\
\text { requirements of } \\
\text { the role }(n)\end{array}$} & \multirow{2}{*}{$\begin{array}{l}\text { OEQ12@ } \\
\text { Team } \\
\text { energy } \\
\text { category }\end{array}$} & \multicolumn{2}{|c|}{ Twenty Statements Test } & \multirow{2}{*}{\begin{tabular}{|l|} 
Interview data \\
What is most notable about this group \\
\end{tabular}} \\
\hline & & $\begin{array}{l}\text { Identification } \\
\text { with role }\end{array}$ & $\begin{array}{l}\text { Ratio and orientation } \\
\text { of reflective statements } \\
\text { in the TST }\end{array}$ & \\
\hline $\begin{array}{l}\text { 1. A self- } \\
\text { confident } \\
\text { leader with a } \\
\text { voice that is } \\
\text { heard }(9 / 34)\end{array}$ & $\begin{array}{l}\text { Highly } \\
\text { productive } \\
\text { energy }\end{array}$ & Owned & $\begin{array}{l}36 \% \\
\text { Reflective statements } \\
\text { tended to be about } \\
\text { their own positive } \\
\text { features and } \\
\text { capabilities, e.g. 'think } \\
\text { creatively', 'on an } \\
\text { exciting journey } \\
\text { learning about myself', } \\
\text { 'the voice of reason', } \\
\text { 'approachable', 'set a } \\
\text { good example' }\end{array}$ & $\begin{array}{l}\text { The majority: } \\
\checkmark \quad \text { personally identify with what they do: it is who they are } \\
\checkmark \quad \text { are excited by doing something new or the prospect of doing } \\
\text { something new AND doing things better } \\
\checkmark \quad \text { focus on resource deficiencies associated with conveying the } \\
\text { meaningfulness of change to others } \\
\checkmark \quad \text { feel they can influence upwards } \\
\checkmark \quad \text { know how to balance big picture and detail } \\
\checkmark \quad \text { tend to have a higher proportion of positive reflective statements } \\
\checkmark \text { about themselves } \\
\quad \text { place less emphasis on their position in the social structure compared } \\
\text { to type } 2\end{array}$ \\
\hline $\begin{array}{l}\text { 2. An officer with } \\
\text { responsibilities } \\
\text { for delivering } \\
\text { results (11/34) }\end{array}$ & $\begin{array}{l}\text { Comfortably } \\
\text { productive } \\
\text { energy }\end{array}$ & Detached & $\begin{array}{l}19 \% \\
\text { A person who is } \\
\text { detached from the role, } \\
\text { has less investment in } \\
\text { reflecting about how to } \\
\text { do things differently, } \\
\text { and is likely to be more } \\
\text { comfortable, BUT also } \\
\text { less likely to learn new } \\
\text { things }\end{array}$ & $\begin{array}{l}\text { The majority: } \\
\checkmark \quad \text { explain their role, skills, behaviours, responsibilities in a detached way } \\
\text { e.g. 'someone who is responsible for' or 'expected to'. They do not } \\
\text { appear to identify personally with what they do: 'A cog in a greater } \\
\text { machine', 'A workhorse - sometimes it's hard to complete all the } \\
\text { activities in } 80 \text { hours' } \\
\checkmark \quad \text { are excited by efficiency, doing things better and want to deliver } \\
\text { performance } \\
\checkmark \quad \text { focus on resource deficiencies like lack of relevant skills, time, spare } \\
\text { capacity } \\
\checkmark \quad \text { tend to describe themselves largely through their position within social } \\
\text { roles and structures } \\
\checkmark \quad \begin{array}{l}\text { were dissatisfied with others' lack of curiosity, motivation to explore or } \\
\text { sense of urgency }\end{array}\end{array}$ \\
\hline
\end{tabular}




\begin{tabular}{|c|c|c|c|c|}
\hline \multirow{2}{*}{$\begin{array}{l}\text { Source } \\
\text { Orientation to the } \\
\text { requirements of } \\
\text { the role }(\mathrm{n})\end{array}$} & \multirow{2}{*}{$\begin{array}{l}\text { OEQ12C } \\
\text { Team } \\
\text { energy } \\
\text { category }\end{array}$} & \multicolumn{2}{|c|}{ Twenty Statements Test } & \multirow{2}{*}{$\begin{array}{l}\text { Interview data } \\
\text { What is most notable about this group }\end{array}$} \\
\hline & & $\begin{array}{l}\text { Identification } \\
\text { with role }\end{array}$ & $\begin{array}{l}\text { Ratio and orientation } \\
\text { of reflective statements } \\
\text { in the TST }\end{array}$ & \\
\hline & & & & $\begin{array}{l}\checkmark \quad \text { emphasise activities that are about encouraging, caring or developing } \\
\text { their team } \\
\checkmark \quad \text { This group is split almost 50:50 in terms of their sense of a capacity to } \\
\text { influence upwards }\end{array}$ \\
\hline $\begin{array}{l}\text { 3. A team player } \\
\text { who engages } \\
\text { with the } \\
\frac{\text { familiar and }}{\text { known }(2 / 34)}\end{array}$ & $\begin{array}{l}\text { Too } \\
\text { comfortable }\end{array}$ & Owned & $\begin{array}{l}10 \% \\
\text { Conversely, this group } \\
\text { was the least reflective, } \\
\text { yet owned their } \\
\text { statements about their } \\
\text { role. An examination of } \\
\text { the detail of their } \\
\text { profile suggests that } \\
\text { they are highly affiliated } \\
\text { with their teams, so the } \\
\text { comfortable energy } \\
\text { may come from social } \\
\text { concerns to do a good } \\
\text { job for the team and a } \\
\text { focus on opportunity to } \\
\text { do the same things } \\
\text { better. }\end{array}$ & $\begin{array}{l}\text { This group was too small to draw strong conclusions. However, they were } \\
\text { characterised by a: } \\
\checkmark \quad \text { focus on responsibilities and expectations of them in their role within } \\
\text { the team and not beyond } \\
\checkmark \quad \text { sense of being vaguely unsettled by the others' dis-ease, but it was not } \\
\text { provoking proactive engagement with learning and change }\end{array}$ \\
\hline $\begin{array}{l}\text { Ambivalent } \\
\text { about their } \\
\text { position and } \\
\text { feeling } \\
\text { conflicted and } \\
\text { vulnerable } \\
(7 / 34)\end{array}$ & Turbulent & Mixed & $\begin{array}{l}60 \% \\
\text { The most reflective } \\
\text { group, yet far more } \\
\text { reflections focused on } \\
\text { constraints and } \\
\text { negative aspects of self } \\
\text { in role, e.g. 'impatient', } \\
\text { 'not IT savvy', }\end{array}$ & $\begin{array}{l}\text { The majority: } \\
\checkmark \quad \text { focused predominantly on resource deficiencies like lack of } \\
\text { relevant skills, time, spare capacity } \\
\checkmark \quad \text { personally identified with some parts of their role, detached from } \\
\text { others, when they had insufficient resources to cope. } \\
\checkmark \quad \text { talked of themselves as 'squeezed', 'a buffer', 'torn' or } \\
\text { unconvinced about the change }\end{array}$ \\
\hline
\end{tabular}




\begin{tabular}{|c|c|c|c|c|}
\hline \multirow{2}{*}{$\begin{array}{l}\text { Source } \\
\text { Orientation to the } \\
\text { requirements of } \\
\text { the role }(n)\end{array}$} & \multirow{2}{*}{$\begin{array}{l}\text { OEQ12C } \\
\text { Team } \\
\text { energy } \\
\text { category }\end{array}$} & \multicolumn{2}{|c|}{ Twenty Statements Test } & \multirow{2}{*}{$\begin{array}{l}\text { Interview data } \\
\text { What is most notable about this group }\end{array}$} \\
\hline & & $\begin{array}{l}\text { Identification } \\
\text { with role }\end{array}$ & $\begin{array}{l}\text { Ratio and orientation } \\
\text { of reflective statements } \\
\text { in the TST }\end{array}$ & \\
\hline & & & $\begin{array}{l}\text { 'unambitious', 'don't } \\
\text { enjoy networking', 'in a } \\
\text { vicious circle', } \\
\text { 'responsible with limited } \\
\text { authority', 'vulnerable'. }\end{array}$ & $\begin{array}{l}\checkmark \quad \text { showed strong team affiliation, and focus on delivery and } \\
\text { performance } \\
\checkmark \quad \text { seem unable to distinguish big picture priorities from detailed } \\
\text { requirements } \\
\checkmark \quad \text { expressed divided loyalties in handling team and organisational } \\
\text { needs e.g. 'It's really a vicious circle that I'm finding myself in. My } \\
\text { team are new, need support and development. I'm doing a lot of } \\
\text { things as expectations from above keep growing. So, I don't have } \\
\text { time to develop and coach them. It's a catch-22 situation' } \\
\text { were the most reflective group in terms of their personal } \\
\text { statements, BUT those reflections were generally self-critical or } \\
\text { centred on negative factors, failures and struggles e.g. 'complete } \\
\text { the unachievable' 'don't enjoy networking' 'easily bored' 'low } \\
\text { authority, high responsibility' }\end{array}$ \\
\hline $\begin{array}{l}\text { 5. Emotionally } \\
\text { exhausted by } \\
\text { uncertainty } \\
\text { and the } \\
\text { volume and } \\
\text { nature of } \\
\text { demands } \\
(3 / 34)\end{array}$ & Resigned & Mixed & $\begin{array}{l}34 \% \\
\text { Reflections focused on } \\
\text { the issues of the gap } \\
\text { between expectations } \\
\text { and capacity to deliver: } \\
\text { 'Expected to deliver on } \\
\text { work objectives', 'Can't } \\
\text { see how initiatives } \\
\text { relate to my work, no } \\
\text { time to get involved', } \\
\text { 'Expected to engage', } \\
\text { 'Feel like I am between } \\
\text { a rock and a hard } \\
\text { place.' }\end{array}$ & $\begin{array}{l}\text { This group was too small to draw strong conclusions. However, they were } \\
\text { characterised by: } \\
\checkmark \quad \text { a lack of emotional commitment - 'none of us can see the benefits' } \\
\checkmark \\
\text { copense that expectations exceeded their personal resources to } \\
\text { com - 'I feel like I am between a rock and a hard place' }\end{array}$ \\
\hline
\end{tabular}




\begin{tabular}{|c|c|c|c|c|}
\hline \multirow{2}{*}{$\begin{array}{l}\text { Source } \\
\text { Orientation to the } \\
\text { requirements of } \\
\text { the role }(n)\end{array}$} & \multirow{2}{*}{$\begin{array}{l}\text { OEQ12C } \\
\text { Team } \\
\text { energy } \\
\text { category } \\
\end{array}$} & \multicolumn{2}{|c|}{ Twenty Statements Test } & \multirow{2}{*}{$\begin{array}{l}\text { Interview data } \\
\text { What is most notable about this group }\end{array}$} \\
\hline & & $\begin{array}{l}\text { Identification } \\
\text { with role }\end{array}$ & $\begin{array}{l}\text { Ratio and orientation } \\
\text { of reflective statements } \\
\text { in the TST }\end{array}$ & \\
\hline $\begin{array}{l}\text { 6. } \frac{\text { Fish out of }}{\text { water, }} \\
\text { struggling to } \\
\text { survive }(2 / 34)\end{array}$ & $\begin{array}{l}\text { Largely } \\
\text { corrosive }\end{array}$ & Detached & $\begin{array}{l}28 \% \\
\text { The anomaly here is } \\
\text { that the personal } \\
\text { reflections on self were } \\
\text { very positive: 'turn my } \\
\text { hand to anything', } \\
\text { 'driver', self-developer', } \\
\text { 'adaptable', sense of } \\
\text { fun', 'seeking } \\
\text { improvement'. Yet the } \\
\text { rest of their interview } \\
\text { responses suggest a } \\
\text { sense of frustration and } \\
\text { incapacity to have an } \\
\text { impact through their } \\
\text { chosen approaches. } \\
\text { This group has the } \\
\text { highest number of } \\
\text { statements per person, } \\
\text { perhaps suggesting a } \\
\text { desire to evidence how } \\
\text { much they have to cope } \\
\text { with. }\end{array}$ & $\begin{array}{l}\text { This group was too small to draw strong conclusions. However, they were } \\
\text { characterised by: } \\
\checkmark \quad \text { a focus on resource deficiencies associated with psychological } \\
\text { safety (no sense of influence, no opportunity to feedback, no } \\
\text { collaborative support) } \\
\checkmark \quad \text { their inability to see their way out of an emotionally overwhelming } \\
\text { combination of demands that make them feel inadequate in their } \\
\text { role. 'A general dogsbody', 'Not cut out to be a strategic go-getter } \\
\text { but wouldn't want to be more junior', 'Knowledge is power' }\end{array}$ \\
\hline
\end{tabular}




\section{Interpreting the energy dynamics surrounding middle manager practice}

When viewed together, the findings provide some interesting early indicators what how MMs orientation to self in role may intersect with positive or negative team energy.

Giangreco and Peccei's (2005) empirical study of MMs resistance to change noted that generally they don't actively resist, rather they fail to proactively engage in change behaviour. Looking at the findings in the lower positive energy groups, there are several factors that could detract from proactive change behaviours. In the face of physical resource constraints (people, money), MMs in the too comfortable category seem to be devoting more personal resources (time, mental effort) towards keeping their team happy. They also mention resource deficiencies associated with insufficient information to make meaning of the change for others. MMs in the turbulent, resigned and corrosive categories seem to have insufficient strategies for coping with inherent role tensions, feel isolated and lacking in influence, which either leads them to become personally self-critical and/or they show signs of detachment, perhaps in defence of their psychological safety and emotional equanimity. Reflective statements in this group focused heavily on inadequacies and limitations particularly in relation to having no outlets for airing their negative feelings, lack of knowledge and skills to cope and shortage of time to learn new skills.

Many scholars connect reflection with higher levels of individual learning (Moon, 2010) both before, during and after action (Dvora and Tsoukas, 2009, Schön, 1983). In a process view of organisational learning, individual learning will be the motor driving the process. Unlike, Type 1 MMs who show appropriate levels of reflection to action, Type 4 MMs are disproportionately engaged in critical personal reflection and MMs in Types 5 and 6 are conflicted about their own capabilities. Research suggests that that reflection on the meaning of ones work in terms of one's capacity to make a difference and rewarding workplace relationships contribute to positive energy (Fritz et al., 2011), implying that the negative reflection in these areas would depress energy. When viewed in the light of the negative team energy profiles these types of MMs manage, it may be that the climate in which the reflections arise distorts the potential learning value of personal reflection. When stretched beyond a feeling of competence, reflection may become damagingly introspective and the lack of perception of positive action in the MM role diminishes a sense of coping and achievement.

Potentially, such dynamics undermine the progress of organisational learning, by depressing group sensitivities and dispositions to cope and adjust. MMs personal insecurities and frustrations potentially distort what they notice, bias decisions and negatively colour interpretations and sensegiving (Beck and Plowman, 2009). They risk further demotivating staff and fuelling an damaging socio emotional climate in a kind of vicious downward spiral (Masuch, 1985).

Conversely, in the positive energy group, three things seem to distinguish MMS in the highly productive team energy category from those in the comfortably productive one. Namely their confidence to influence upwards, a drive to make change meaningful for others and a wholly internalised 
ownership of their role. MMs in this category actively describe their role as leadership, inspiring and stretching others, as opposed to simply someone with functional responsibilities or a manager co-ordinating a team with limited resources. As they influence upwards to revise ongoing TMT sensemaking, they would be engaging in conversations that allows them to co-ordinate their own activities better, which should increase their personal energy for change (Quinn and Dutton, 2005) and also help them re-interpret strategic direction through feedback (Hope, 2010). MMs in this category seem energized by the tensions inherent in the role experiencing the stretch as positive rather than negative. Their capacity to connect the big picture with the detailed of practice enables them to make things more meaningful to their teams in the sensegiving process. Collectively this may give everyone more sense of influence over the meaning of their work and their capacity to make a difference, which has been argued to be a source of positive energy in knowledge workers (Fritz et al., 2011). Additionally, in the organisational learning process, already acknowledged to be political and negotiated (Lawrence et al., 2005), assuming a leadership persona with upwards influence is likely to endow an MM with a mantle of power that contributes to the productive energy of the group in a kind of virtuous cycle of positive feedback.

Overall there is a sense that more proactive engagement with change would emerge if organisations did more to help make change meaningful at MMs level, so that they feel less tension, and more able to cope with the other more physical resource constraints. Chia argues that in practice, it is not possible or desirable to provide MMs with 'preset goals' and 'precharted maps', ' what is more appropriate for guiding response, therefore, is a practice-driven, sensory-based form of learning that allows for constant searching, adjustments, reconfiguration of responses and re-education of attention to emergent issues at hand.' (2017 p. 114). By implication the process of searching and adjustment will be enriched by heighten sensitivity to the diversity of available opportunities, information and insights within the team. When resources are constrained, MMs available time and energy is spread thin. As a result the collective appetite for searching and the collective disposition to explore alternative perspectives, challenge assumptions and reflect on different experiences may be suppressed. Keeping the team happy, managing internal conflict and their own insecurities drains energy and limits learning.

\section{Conclusion}

When organisational learning is viewed as a process of ongoing navigation, adaptation and change, middle managers becomes influential in shaping the pace and direction and spread of learning across the organisation. This research suggests that middle managers' perceptions of self in role have a bearing on the collective energy available to invest in learning for themselves and within their team. How MMs enact their practice appears to be intricately entangled with the social dynamics around them in their relationships within their teams and with the TMT. Managers of teams with energy levels that are overly comfortable or moving towards the negative end of the energy spectrum devote more effort on managing the emotional climate in the team leaving less available for investing in sensing opportunities and transforming them into new collective praxis. Inevitably this limits the potential for moving the organisation towards high level strategic goals through organisational learning activity. Although, in reality, MMs will probably remain overstretched and squeezed by limited access to financial and human resources with the necessary skills, this research suggests that boosting their personal resources could 
help them focus their limited time and energy on more productive activities. This has practical implications for anyone with a remit for organisational development (OD), learning and development (L\&D), organisational learning (OL) and/or knowledge management (KM). OD teams are well placed to offer support for MMs sensemaking and sensegiving activities by facilitating large group interventions designed to make change more meaningful for teams across the organization. $L \& D$ teams could provide developmental opportunities for MMs that encourage them to explore what leadership means for them. $\mathrm{OL}$ and $\mathrm{KM}$ teams could provide support for an MM community of practice where good practice in dealing with tensions and resource constraints can be shared. Improving communication channels between MMs and the TMT could enhance MMs understanding of why change matters, what their role is within it and how their teams fit into the bigger picture. 


\section{References (750)}

Ahearne, M., Lam, S. K. \& Kraus, F. 2014. Performance impact of middle managers' adaptive strategy implementation: The role of social capital. Strategic Management Journal, Vol. 35 No. 1, pp. 68-87.

Argote, L. \& Miron-Spektor, E. 2011. Organizational learning: From experience to knowledge. Organization Science, Vol. 22 No. 5, pp. $1123-1137$.

Beck, T. E. \& Plowman, D. A. 2009. Experiencing rare and unusual events richly: The role of middle managers in animating and guiding organizational interpretation. Organization Science, Vol. 20 No. 5, pp. 909-924.

Bourdieu, P. 1989. Social space and symbolic power. Sociological Theory, Vol. 7 No. 1, pp. 14-25.

Bruch, H. \& Vogel, B. 2011. Fully charged: How great leaders boost their organization's energy and ignite high performance, Harvard Business School Publishing, Boston MA.

Carlile, P. R. 2004. Transferring, translating and transforming: An integrative framework for managing knowledge across boundaries. Organization Science, Vol. 15 No. 5, pp. 555-568.

Chia, R. 2017. A process-philosophical understanding of organizational learning as "wayfinding": Process, practices and sensitivity to environmental affordances". The Learning Organization, Vol. 24 No. 2, pp. 107-188.

Cole, M. S., Bruch, H. \& Vogel, B. Emotions as mediators of perceived supervisor support and psychological hardiness on cynicism. Academy of Management Proceedings, 2004. Academy of Management Briarcliff Manor, NY 10510, Q1-Q6.

Cole, M. S., Bruch, H. \& Vogel, B. Development and validation of a measure of organizational energy. Academy of Management Proceedings, 2005. Academy of Management Briarcliff Manor, NY 10510, V1-V6.

Cole, M. S., Bruch, H. \& Vogel, B. 2012. Energy at work: A measurement validation and linkage to unit effectiveness. Journal of Organizational Behavior, Vol. 33 No. 4, pp. 445-467.

Crossan, M. M., Lane, H. W. \& White, R., E 1999. An organizational learning framework: From intuition to institution. Academy of Management Review, Vol. 24 No. 3, pp. 522-537.

Currie, G. \& Procter, S. J. 2005. The antecedents of middle managers' strategic contribution: The case of a professional bureaucracy. Journal of Management Studies, Vol. 42 No. 7, pp. 1325-1356.

Dvora, Y. \& Tsoukas, H. 2009. What is reflection in action: A phenomenological account. Journal of Management Studies, Vol. 46 No. 8, pp. $1339-1364$.

Farjoun, M. 2010. Beyond dualism: Stability and change as a duality. Academy of Management Review, Vol. 35 No. 2, pp. 202-225.

Fritz, C., Lam, C. F. \& Spreitzer, G. M. 2011. It's the little things that matter: An examination of knowledge workers' energy management. Academy of Management Perspectives, Vol. 25 No. 3, pp. 28-39.

Giangreco, A. \& Peccei, R. 2005. The nature and antecedents of middle manager resistance to change: Evidence from an italian context. International Journal of Human Resource Management, Vol. 16 No. 10, pp. 1812-1829.

Graetz, F. \& Smith, A. C. T. 2010. Managing organizational change: A philosophies of change approach. Journal of Change Management, Vol. 10 No. 2 , pp. $135-154$

Hope, O. 2010. The politics of middle management sensemaking and sensegiving. Journal of Change Management, Vol. 10 No. 2, pp. 195-215. 
Huy, Q. N. 2001. In praise of middle managers. Harvard Business Review, Vol. 79 No. 8, pp. 72-79.

Huy, Q. N. 2002. Emotional balancing of organizational continuity and radical change: The contribution of middle managers. Administrative Science Quarterly, Vol. 47 No. 1, pp. 31-69.

Huy, Q. N. 2011. How middle managers' group-focus emotions and social identities influence strategy implementation. Strategic Management Journal, Vol. 32 No. 13, pp. 1387-1410.

Jermy, S. 2011. Strategy for action: Using force wisely in the 21st century, Knightstone Publishing, London.

Kuhn, M. H. \& Mcpartland, T. S. 1954. An empirical investigation of self-attitudes. American sociological review, Vol. 19 No. 1 , pp. 68-76.

Kwon, S.-W. \& Adler, P. S. 2014. Social capital: Maturation of a field of research. Academy of Management Review, Vol. 39 No., pp. $412-422$.

Lawrence, T. B., Mauws, M. K., Dyck, B. \& Kleysen, R. F. 2005. The politics of organizational learning: Integrating power into the 4i framework. Academy of Management Review, Vol. 30 No. 1, pp. 180-191.

Lewis, M. W., Andriopoulos, C. \& Smith, W. K. 2014. Paradoxical leadership to enable strategic agility. California Management Review, Vol. 56 No. 3, pp. 5877.

Lüscher, L. S. \& Lewis, M. W. 2008. Organizational change and managerial sensemaking: Working through paradox. Academy of Management Journal, Vol. 51 No. 2, pp. 221-240.

Macintosh, R., Beech, N., Bartunek, J., Mason, K., Cooke, B. \& Denyer, D. 2017. Impact and management research: Exploring relationships between temporality, dialogue, reflexivity and praxis. British Journal of Management, Vol. 28 No. 1, pp. 3-13.

Masuch, M. 1985. Vicious circles in organizations. Administrative Science Quarterly, Vol. 30 No. 1, pp. 14-33.

Miaskiewicz, T. \& Kozar, K. A. 2011. Personas and user-centered design: How can personas benefit product design processes? Design Studies, Vol. 32 No. 5, pp. 417-430.

Moon, J. A. 2010. Reflection in learning and professional development, Routledge Falmer, New York.

Nahapiet, J. \& Ghoshal, S. 1998. Social capital, intellectual capital and the organizational advantage. Academy of Management Review, Vol. 23 No. 2, pp. 242-267.

Naiman, S. 2009. Generating positive energy in the workplace during hard times. Employment Relations Today (Wiley), Vol. 36 No. 1, pp. $49-55$.

Nasim, S. \& Sushil 2011. Revisiting organizational change: Exploring the paradox of managing continuity and change. Journal of Change Management, Vol. 11 No. 2, pp. 185-206.

Orlikowski, W. J. 2002. Knowing in practice: Enacting a collective capability in distributed organizing. Organization Science, Vol. 13 No. 3, pp. $249-273$.

Quinn, R. W. \& Dutton, J. E. 2005. Coordination as energy-in-conversation. Academy of Management Review, Vol. 30 No. 1, pp. 36-57.

Quinn, R. W., Spreitzer, G. M. \& Lam, C. F. 2012. Building a sustainable model of human energy in organizations: Exploring the critical role of resources. The Academy of Management Annals, Vol. 6 No. 1, pp. 337-396.

Raes, A. M. L., Heijltjes, M. G., Glunk, U. \& Roe, R. A. 2011. The interface of the top management team and middle managers: A process model. Academy of Management Review, Vol. 36 No. 1, pp. 102-126.

Reay, D. 2004. 'It's all becoming a habitus': Beyond the habitual use of habitus in educational research. British Journal of Sociology of Education, Vol. 25 No. 4, pp. 431-444. 
Rees, A. \& Nicholson, N. 2004. The twenty statements test. In: CASSELL, C. \& SYMON, G. (eds.) Essential guide to qualitative research methods in business research. Sage publications, London.

Rouleau, L. 2005. Micro-practices of strategic sensemaking and sensegiving: How middle managers interpret and sell change every day. Journal of Management Studies, Vol. 42 No. 7, pp. 1413-1441.

Schön, D. A. 1983. The reflective practitioner: How professionals think in action, Jossey-Bass, San Franscisco.

Seo, M.-G., Bartunek, J. M. \& Barrett, L. F. 2010. The role of affective experience in work motivation: Test of a conceptual model. Journal of Organizational Behavior, Vol. 31 No. 7, pp. 951-968.

Sharma, G. \& Good, D. 2013. The work of middle managers: Sensemaking and sensegiving for creating positive social change. Journal of Applied Behavioral Science, Vol. 49 No. 1, pp. 95-122.

Shepherd, D. A., Patzelt, H. \& Wolfe, M. 2011. Moving forward from project failure: Negative emotions, affective commitment, and learning from the experience. Academy of Management Journal, Vol. 54 No. 6, pp. 1229-1259.

Siddiqi, S., Goralski, M. A. \& Tootoonch, A. 2012. Energy generators - energy drainers: The intangible ripples of corporate energy. International Journal of Business \& Public Administration, Vol. 9 No. 1, pp. 70-81.

Vaara, E. \& Whittington, R. 2012. Strategy-as-practice: Taking social practices seriously. The Academy of Management Annals, Vol. 6 No. 1, pp. 285-336.

Van De Ven, A. H. 2007. Engaged scholarship: A guide for organizational and social research, Oxford University Press, Oxford.

Van De Ven, A. H. \& Johnson, P. E. 2006. Knowledge for theory and practice. Academy of Management Review, Vol. 31 No. 4, pp. 802-821.

Van Winkelen, C., Birchall, D. \& Mckenzie, J. Exploring relevance: A case study of an interactive research method within the context of an interorganizational community of practice. Bristish Academy of Management, 9-11 September 2008 Harrogate.

Van Winkelen, C. \& Truch, E. An assessment of the interactive research method using a multi-project case example. European Conference on Research Methods, April 29-30 2002 University of Reading.

Vijay, M. \& Vazirani, N. 2011. Emerging paradigm - fun in workplace to alleviate stress. SIES Journal of Management, Vol. 7 No. 2, pp. $24-30$.

Voronov, M. \& Vince, R. 2012. Integrating emotions into the analysis of institutional work. Academy of Management Review, Vol. 37 No. 1, pp. 58-81. 